\title{
PhDr. Viera Gašparíková, DrSc. sa dožila významného životného jubilea
}

\author{
Hana Hlôšková (Bratislava)
}

Významná slovenská folkloristka, Viera Gašparíková, spojila celý svoj odborný život s tradičnou l’udovou slovesnostou. Koncom mája sa s ňou pri príležitosti jej 90. narodenín jej kolegyne a kolegovia stretli na pracovnom seminári a na spoločenskom posedení. Jubilantka sa dožila jubilea v plnej duševnej sviežosti, a tak ani vel’mi neprekvapila prítomných, ked’ predniesla odborný referát. Aká bola pút jubilantky za poznávaním ludovej prózy - jej tém, žánrov, nositel’ov a života?

Viera Gašparíková sa narodila 15. 4. 1928 v Martine v učitel'skej rodine s tromi detmi. Po maturite na gymnáziu sa zapísala na Filozofickú fakultu Univerzity Komenského (v tom čase Slovenská univerzita) v Bratislave, kde študovala slovenský jazyk a literatúru, francúzsky jazyk a literatúru a národopis, ktorý sa vtedy prednášal v rámci Katedry histórie a archeológie.

Jej záujem o literatúru a národopis sa začal formovat’ už počas gymnaziálneho štúdia v Martine najmä pôsobením v Samovzdelávacom krúžku a pod vplyvom profesorov, z ktorých niektorí začali pôsobit čoskoro na bratislavskej univerzite (R. Bednárik, R. Brtáň). Vysokoškolské štúdiá ukončila v roku 1952 doktorátom filozofie (PhDr.). Hoci už počas štúdia pracovala ako asistentka na katedre národopisu, nebolo jej dopriate tam aj nad'alej pôsobit'. V rokoch 1953-1956 pracovala ako redaktorka v časopise Život a ako šéfredaktorka časopisu Výtvarný život.

Po nástupe do Národopisného ústavu SAV v roku 1956 bola vyslaná na ašpirantské štúdium na Katedru etnografie a folkloristiky Filozofickej fakulty Univerzity Karlovej v Prahe, aby sa po jeho ukončení venovala problematike ludovej prózy. Hodnost̉ kandidáta vied (CSc.) získala v roku 1960 na základe práce Zbojník Michal Vdovec v histórii a folklóre gemerského l’udu. V polovici šesṫdesiatych rokov ju vedenie Národopisného ústavu SAV poverilo spracovat vedecko-porovnávacie komentáre k edícii Slovenské l'udové rozprávky, avšak vtedajšia klíma nebola priaznivo naklonená klasickým spracovaniam edícia, kompletne pripravená do tlače, bola uložená do archívu Slovenskej akadémie vied. Preto sa V. Gašparíková venovala riešeniu iných, v tom čase aktuálnych tém slovesnej folkloristiky. Vo svojej terénnej a teoretickej práci sa venovala niekol'kým ústredným témam. Predovšetkým je to štúdium tematiky odboja v prozaickom folklóre na Slovensku, zbieranie a štúdium slovenskej ludovej prózy, intenzívne spojené so systematickou porovnávacou a katalogizačnou prácou a v širšom medzinárodnom, predovšetkým však slovanskom kontexte. Venovala sa problematike l’udovej prózy v jej širokých súvislostiach textologických, žánrových či klasifikačných a syntetizujúc svoje poznatky z početných 
terénnych výskumov dospievala ku komparatívnym záverom v širších interregionálnych a medzietnických súvislostiach.

V. Gašparíková poznanie problematiky sociálnej revolty v 18. storočí rozšírila poznatkami o historicky d’alšej etape - o súmraku zbojníctva na Slovensku v 19. storočí. Jeho obrazu v prozaickom folklóre sa venovala v prácach Zbojnik Michal Vdovec v histórii a folklóre gemerského ludu (1964), Zbojnik Mišo Vdovč̌k (1966), Zbójnicki dar (1976), Povesti o zbojnikoch zo slovenských a pol’ských Tatier (1979). Antológia Jánošik, ktorá vyšla v roku 1988, je komplexným obrazom zbojníckej tradície v národných kultúrach Čechov a Slovákov. V rámci širšieho porovnávacieho štúdia V. Gašparíková metodologicky, organizačne i editorsky prispela v medzinárodnej spolupráci k vydaniu medzinárodnej syntézy o folklórnych tradíciách v Karpatoch, ktorá vyšla v rusko-anglickej verzii pod názvom Heroes or Bandits? - Geroj ili zbojnik? (2002).

Logickým nadviazaním na výsledky štúdia l’udových odbojových tradícií bol i výskum folklórneho stvárnenia udalostí Slovenského národného povstania a početné štúdie o obraze hrdinu protifašistického odboja, o vztahu historickej skutočnosti a jej folklórnej interpretácie.

Početné štúdie venovala poetike jednotlivých prozaických žánrov, dejinám folkloristiky, pričom svoje poznatky syntetizovala v publikácii Slovenská l’udová próza a jej súčasné vývinové tendencie (1986), vydanej v roku 1988 aj v zahraničí v mad’arskom jazyku.

Špecifické povahové vlastnosti ju predurčili na jedno z klasických odvetví folkloristiky - na klasifikáciu a katalogizáciu l’udovej prózy. Výsledkom je Katalóg slovenskej l’udovej prózy I-II (1991-1992).

O dôvernej znalosti celého spektra žánrov tradičnej prózy svedčia aj monografie jednotlivých žánrov - publikačne sprístupnila humoristické rozprávania v publikácii Ostrovtipné príbehy a veliké cigánstva a žarty (1980), čarovné rozprávky Zlatá podkova, zlaté pero, zlatý vlas I-II (1984-1985). Viera Gašparíková dlhodobou prácou nad textovým spracovaním, vedecko-porovnávacími komentármi a štúdiou zhodnotila v edícii Slovenské l’udové rozprávky I-III (1993, 2001, 2004) rozprávačský fond, ktorý v rámci terénnych výskumov zaznamenali v medzivojnovom období študenti Slovanského seminára pod vedením prof. F. Wollmana. Takto zameraná je aj publikácia Slowakische Volksmärchen, ktorá vyšla v Nemecku v roku 2000.

Vo svojej komparatívne zameranej práci sa sústredila predovšetkým na medzislovanské vztahy v knihe Spievajúca lipka. Rozprávky západných Slovanov (1972) a svoje poznatky prezentovala od roku 1963 vo viacerých štúdiách a referátoch na Medzinárodných zjazdoch slavistov (Sofia, Praha, Varšava, Záhreb, Kyjev, Bratislava, Krakov, Lublana). V roku 1989 bola jednou z iniciátoriek vzniku a aktívnou členkou redakčného kolektívu Medzinárodného informačného bulletinu Slavistická folkloristika, ktorý je informačným fórom Komisie slovanského folklóru pri Medzinárodnom komitéte slavistov.

V. Gašparíková takmer pol storočia pracovala v Národopisnom ústave SAV (dnes Ústav etnológie SAV), a to od roku 1956-1993 ako určitý čas vedúca oddelenia duchovnej kultúry, vedúca vedecká pracovníčka, redaktorka časopisu Slovenský národopis, edičná referentka a i. Na poli slavistického štúdia sa angažovala ako podpredsedníčka Slovenského komitétu slavistov, ešte stále ako členka výboru. Je členkou domácich a medzinárodných 
vedeckých spoločností (Polskie Towarzystwo Ludoznawcze, International Society for Folk Narrative Research, Société Internationale d'Ethnologie et de Folklore). Z mnohých ocenení, ktorým bol vyzdvihnutý jej kultúrny, vedecký a organizačný prínos, uved’me Čestnú plaketu Medzinárodného komitétu slavistov v Kyjeve, čestný diplom za prácu v slavistickom bádaní v L'ublane a v roku 1988 Slovenská akadémia vied jej udelila zlatú plaketu L'udovíta Štúra za zásluhy v spoločenských vedách. Naposledy jej Medzinárodná jury pre rozprávky v októbri 2008 udelila najvyššie ocenenie Európsku cenu za rozprávky (Europäische Märchenpreis) v nemeckom Volkachu za prítomnosti najvýznamnejších bádatelov rozprávok z celého sveta.

Aj v období po odchode do dôchodku V. Gašparíková aktívne pracovala na viacerých odborných problémoch, venovala sa doktorandkám, oponovala doktorandské práce a k problematike tradičnej prózy vystupovala v médiách.

V budúcom roku uplynie už tridsat rokov odvtedy, ako na moravskej strane v zastúpení O. Sirovátkom (Brno) a na slovenskej strane v zastúpení V. Gašparíkovou (Bratislava) vznikla iniciatíva vydávat medzinárodný informačný bulletin, ktorý by reflektoval dianie v slavisticky zameranej folkloristike. Bulletin vychádzal pravidelne k času konania medzinárodných zjazdov slavistov, tiež však ako občasník v období medzi jednotlivými zjazdmi. Aj k 16. Medzinárodnému zjazdu slavistov, ktorý sa konal v Belehrade v Srbsku v dňoch 20. - 27. 8. 2018, redakcia medzinárodného bulletinu Slavistická folkloristika vydala číslo, ktoré reflektuje prácu a výsledky slavisticky orientovaného bádania vo folkloristike v širšom stredoeurópskom rámci. Belehrad bol určite vynikajúcim hostitelom odborného i kolegiálneho stretnutia slavistov z celého sveta. Účastníci - folkloristi iste prijali v Medzinárodnej komisii slovanského folklóru pri Medzinárodnom komitéte slavistov do budúceho obdobia plány, nadviažuc a rozvinúc ciele, ktoré do vienka Medzinárodnému informačnému bulletinu Slavistická folkloristika vpísali jeho zakladatelia. Bol by to zmysluplný kolegiálny dar V. Gašparíkovej k jej životnému jubileu!

doc. PhDr. Hana Hlôšková, CSc.

Katedra etnológie a muzeológie

Filozofická fakulta, Univerzita Komenského

Gondova 2, 81499 Bratislava, Slovensko

anna.hloskova@uniba.sk 
